\title{
JUDICIAL REVIEW IN THE EU'S COMMON FOREIGN AND SECURITY POLICY
}

\author{
Panos Koutrakos*
}

\begin{abstract}
The EU's Common Foreign and Security Policy (CFSP) was conceived of as an area ill-suited for full judicial review by the Court of Justice of the European Union. The Lisbon Treaty confers on the Court limited jurisdiction which the recent case law has interpreted in broad terms. This article will place this case law in the broader constitutional setting of the EU legal order and will provide a critical analysis of its implications for both the EU's and domestic courts. The analysis is structured on the basis of three main themes. The first is about the position of CFSP in the EU's constitutional architecture: the article will analyse the constitutional ambivalence that characterizes this position and how it is conveyed by the provisions of the Treaty on the European Union and the Treaty on the Functioning of the European Union governing the Court's jurisdiction. The second theme is about the recent case law, and the integrationist approach that the Court of Justice has adopted to the scope of its jurisdiction. The third theme is about national courts: the article will argue that recent case law has been too quick to dismiss them, and that primary law renders them an essential part of the judicial review system governing CFSP.
\end{abstract}

Keywords: Common Foreign and Security Policy, Court of Justice of the European Union, EU law, European Union, judicial review.

\section{INTRODUCTION}

Given that it 'is conventional to think of foreign and security policy as a realm of sovereign wills and national interests par excellence', ${ }^{1}$ what is the proper role for the judiciary in this area? While challenging national legal orders, ${ }^{2}$ this question was viewed with suspicion in the early days of the Common Foreign and Security Policy (CFSP) of the European Union (EU). The

* Professor of European Union Law and Jean Monnet Chair in European Union Law, City, University of London, Panos.Koutrakos.1@city.ac.uk. Many thanks to Joni Heliskoski. All errors and omissions are my own.

${ }^{1}$ M Koskenniemi, 'International Law Aspects of the Common Foreign and Security Policy' in M Koskenniemi (ed), International Law Aspects of the European Union (Martinus Nijhoff 1998) 27, 27.

2 See T Franck, Political Questions, Judicial Answers: Does the Rule of Law Apply to Foreign Affairs? (Princeton University Press 1992). For a broader perspective, see T Poole, 'The Constitution and Foreign Affairs' (2016) 69 Current Legal Problems 143. 
Union's foreign policy initiatives were considered as short-term, wide-ranging and sensitive responses to political crises and, as such, ill-suited for judicial resolution. ${ }^{3}$ This was particularly so in the light of the approach of the European Court of Justice (Court of Justice, or the Court) which was viewed as either distinctly constitutionalizing or positively integrationist in its outlook. It was, therefore, hardly surprising that no role for the Union's judges was envisaged in CFSP matters.

Things, however, have changed. The gradually evolving scope and implications of fundamental human rights have challenged traditional understandings about the impact of the rule of law on the conduct of foreign policy. ${ }^{4}$ As former Advocate General Jacobs put it, "no matter should be automatically a priori excluded from judicial review'. ${ }^{5}$ The entry into force of the Lisbon Treaty in 2009 also reframed the terms in which foreign policy was designed in the reformed EU. The new constitutional arrangements recalibrated the position of CFSP in the Union's architecture and introduced certain exceptions to the absence of jurisdiction of the Court of Justice. It has been against this context that the question about the role of judicial review in the area has been raised with increasing frequency and intensity in the last few years. In its Opinion 2/13 on the Draft Agreement on the EU's accession to the European Convention on Human Rights (ECHR), the Court held that, 'as EU law now stands, certain acts adopted in the context of the CFSP fall outside the ambit of judicial review by the Court of Justice'. ${ }^{6}$ This statement raised, and left open, the question of the delineation of the scope of the Court's jurisdiction.

The urgency of this question is reflected by the important case law of both the Court of Justice and the General Court of the European Union (the combination of which is referred to as 'the Court of Justice of the European Union' or 'CJEU') in the last three years. This case law will be the main focus of this article. The analysis will be structured along three themes. The first is about the position of CFSP in the EU's constitutional architecture: the article will analyse the ambivalence that characterizes this position and the ways in which it is conveyed by the provisions of the Treaty on the European Union (TEU) and the Treaty on the Functioning of the European Union (TFEU) (both will be referred to as 'the Treaties') governing the Court's jurisdiction in CFSP. The second theme is about the recent case law, and the integrationist approach that the Court of Justice has adopted to the interpretation of the scope

${ }^{3}$ E Denza, The Intergovernmental Pillars of the European Union (Oxford University Press 2002) 312 .

${ }_{4}$ See G De Baere, 'European Integration and the Rule of Law in Foreign Policy' in J Dickson and P Eleftheriadis (eds), Philosophical Foundations of European Union Law (Oxford University Press 2012) 354.

${ }^{5}$ Cited in House of Lords, Select Committee on the EU, The Future Status of the EU Charter of Fundamental Rights (HL 2002-03, HL 48) 36 para 144.

${ }^{6}$ Opinion 2/13 (Accession to ECHR) EU:C:2014:2454, para 252. 
of its jurisdiction. The third theme is about national courts: the article will argue that primary law renders them an essential part of the judicial review system governing CFSP, and that recent case law has been too quick to dismiss their role.

\section{THE LEGAL FRAMEWORK: A DEGREE OF AMBIVALENCE?}

The scope of CFSP is as close to high politics as a policy area can get. It covers 'all areas of foreign policy and all questions relating to the Union's security, including the progressive framing of a common defence policy that might lead to a common defence'. ${ }^{7}$ In legal terms, the conduct of CFSP is carried out mainly by three types of decisions: a decision of an operational character, adopted under Article 28 TEU in order to define an action to be undertaken by the EU (for instance on outreach activities in support of the implementation of the Arms Trade Treaty ${ }^{8}$ or the establishment of a military training mission in Central African Republic ${ }^{9}$ ); a decision of a non-operational character, adopted under Article 29 TEU in order to define the Union's position on a particular matter (for instance, on the International Criminal Court ${ }^{10}$ ); a decision defining arrangements for the implementation of a prior decision on an action to be undertaken or a position to be taken by the EU.

The position of CFSP in the Union's constitutional architecture is characterized by two threads that are, at times, in conflict. The first thread is about distinctiveness. The rules governing CFSP are not set out in TFEU, along with the provisions governing all the other strands of the Union's external action (Common Commercial Policy, development cooperation, economic, financial and technical cooperation with third countries, humanitarian aid, restrictive measures, international agreements, the Union's relations with international organizations and third countries and Union delegations). Instead, they are laid down in TEU, ${ }^{11}$ hence making the CFSP the only substantive policy whose rules are not in the TFEU. The Union's competence, furthermore, is distinguished from the other types of EU competences set out in Article 2 TFEU (which lists them as exclusive, shared, coordinating, and supporting and supplementing). The CFSP competence, instead, is listed separately in Article 2(4) TEU. The distinct nature of the set of rules governing this area is underlined in Article 24(1) subparagraph 2 TEU, according to which the CFSP 'is subject to specific rules and procedures'. It is also borne out by the applicable institutional structure and procedural framework: no legislative acts may be adopted, ${ }^{12}$ the Council acts, in principle, unanimously, ${ }^{13}$ the right of initiative is shared by the High Representative of the Union for Foreign Affairs and Security Policy with

\footnotetext{
7 Art 24(1) TEU. $\quad{ }^{8}$ Council Dec 2017/915/CFSP [2017] OJ 139/38.

9 Council Dec 2016/610/CFSP [2016] OJ L 104/21. $\quad{ }^{10}$ Council Dec 2011/168/CFSP

11 Title V, Chapter 2 TEU. $\quad{ }^{12}$ Art 24(1) para 2 TEU and art 31(1) TEU.

13 Art 24(1) para 2 TEU and art 31 TEU.
} 
the Member States, ${ }^{14}$ the European Parliament does not participate in decisionmaking and its role is extremely limited. ${ }^{15}$

This thread of distinctiveness is not novel. It was shared both by the precursor to the CFSP, that is the European Political Co-operation (EPC), ${ }^{16}$ which acquired primary law status in the Single European Act in 1986, and the rules governing the CFSP prior to the entry into force of the Lisbon Treaty in 2009. ${ }^{17}$ The organization of CFSP on the basis of distinct characteristics reflects the unique constitutional position of the set of rules governing this policy area: it suggests that the special normative features which shaped the sui generis nature of the Community legal order and in light of which the Court of Justice had pronounced it 'a new legal order of international law for the benefit of which the Member States have limited their sovereign rights, albeit within limited fields' ${ }^{\prime} 18$ were absent from the CFSP.

The second thread running through the CFSP rules is about integration in the Union's overall architecture. The Lisbon Treaty reconfigured the Union's constitutional order by abolishing the tripartite pillar structure and, for the first time in the Union's constitutional history, articulating in Article 21 TEU a set of principles and objectives which govern all external policies. ${ }^{19}$ The CFSP is, therefore, carried out pursuant to a single legal framework and on the basis of principles and objectives which it shares with the other strands of the EU's external activities. The significance of this change was highlighted, in another context, by the recent Opinion on the conclusion of the EU-Singapore Free Trade Agreement where the Court stressed the obligation to integrate these principles and objectives (and, in particular, the one about sustainable development) in the Union's external trade policy. ${ }^{20}$ In this vein, the Treaties introduce for the first time the term 'external action' to describe everything that the EU does in the world, including in CFSP. The singular term chosen by the drafters of the Treaties conveys an understanding of the different strands of the Union's external policies (trade, economic, development, social, political, security) as an integrated whole.

These threads of distinctiveness and integration suggest a degree of ambivalence as to the legal position of CFSP in the Union's constitutional order. This is borne out by the only primary provision that tackles the co-

14 Art 30(1) TEU.

15 Art 36 TEU.

16 See S Nuttall, 'European Political Co-operation and the Single European Act' (1985) 5 YEL 203; S Perrakis, 'L'incidence de l'Acte Unique Européen sur la Coopération des Douze en Matière de Politique Etrangère' (1988) XXXIV AFDI 807. On the legal effect of those provisions, see C Bosco, 'Commentaire de l'Acte Unique Européen des 17-28 Fevrier 1987' (1987) XXIII CDE 355, 381; J-P Jacqué, ‘L’Acte unique européen' (1986) 22 RTDE 575, 611.

17 See the analysis in E Denza, The Intergovernmental Pillars of the European Union (Oxford University Press 2002).

18 Case 26/62 Van Gend en Loos [1963] ECR 1 at 12. Less than 30 years later, the Court held that the Member States had limited their sovereign rights 'within ever wider fields': Opinion 1/91 (re: Draft EEA Agreement) EU:C:1991:490 at para 21.

19 See J Larik, Foreign Policy Objectives in European Constitutional Law (Oxford University Press 2016).

${ }^{20}$ Opinion 2/15 EU:C:2017:376, paras 140ff. 
existence of CFSP with the other external policies of the Union within a single legal framework, that is Article 40 TEU. It reads as follows:

The implementation of the common foreign and security policy shall not affect the application of the procedures and the extent of the powers of the institutions laid down by the Treaties for the exercise of the Union competences referred to in Articles 3 to 6 of the Treaty on the Functioning of the European Union.

Similarly, the implementation of the policies listed in those Articles shall not affect the application of the procedures and the extent of the powers of the institutions laid down by the Treaties for the exercise of the Union competences under this Chapter.

The above provision acknowledges the fundamental differences that distinguish the CFSP framework from that governing the other strands of the Union's external action. ${ }^{21}$ In essence, it requires that the distinct procedural and institutional characteristics of CFSP, on the one hand, and the other external policies of the Union, on the other hand, should not be encroached upon. This is imperative, as the above characteristics define the normative qualities of the respective legal frameworks in distinct terms. In fact, Article 40 TEU highlights this distinction more starkly than the pre-Lisbon constitutional arrangements did: the Amsterdam and Nice Treaties included a similar provision, except that it only prevented any CFSP measure from impinging upon the Community legal order. ${ }^{22}$ By amending Article 40 TEU in order to place CFSP on an equal footing with the other EU policies, the Lisbon Treaty underlines the distinct nature of its rules and procedures in the Union's constitutional order. ${ }^{23}$

The way in which primary law approaches the jurisdiction of the Court on CFSP matters reflects the above two threads of distinctiveness and integration. The Treaties set out the general jurisdiction of the Court in broad terms: Article 19(1) TEU provides that the Court of Justice of the European Union 'shall ensure that in the interpretation and application of the Treaties the law is observed'. There is, however, an exclusion of CFSP matters from the Court's jurisdiction. This has been part of primary law since provisions on foreign and security policy were introduced, first in the Single European Act in relation to the European Political Co-operation, and then at Maastricht all the way through to Lisbon. This exclusion is part of Title V Chapter 2 TEU, entitled 'Specific provisions on the Common Foreign and Security Policy', and is laid down in Article 24(1) subparagraph 2 TEU, according to which ' $[\mathrm{t}]$ he Court of Justice of the European Union shall not have

\footnotetext{
21 See also D Thym, 'The Intergovernmental Constitution of the EU's Foreign, Security and Defence Executive' (2011) 7 European Constitutional Law Review $453 . \quad 22$ Ex art 47 TEU.

${ }^{23}$ For another understanding of the position of CFSP in the EU's constitutional order, with emphasis on the former as a fully integrated part of the latter, see M Cremona, 'The CFSP-CSDP in the Constitutional Architecture of the EU' in S Blockmans and P Koutrakos (eds), Research Handbook on CFSP/CSDP (Elgar Publishing, forthcoming).
} 
jurisdiction with respect to these provisions ...'. It is also laid down in Article 275 TFEU, according to which '[t]he Court of Justice of the European Union shall not have jurisdiction with respect to the provisions relating to the common foreign and security policy nor with respect to acts adopted on the basis of those provisions'.

Whilst this exclusion has been part of the DNA of the Union's foreign and security policy, CFSP matters were not conceived of as hermetically sealed from all other areas of EU law. For instance, secondary rules on access to Council documents were held quite early on to be applicable, in principle, to documents adopted in the CFSP area as well, as no specific exception was laid down thereunder. ${ }^{24}$ It was the Lisbon Treaty, however, that introduced for the first time two exceptions to the CFSP exclusion. The first is about the dividing line between CFSP and the other areas of EU law (for instance, this would cover a case where a measure adopted under CFSP rules should have been adopted under other EU rules). The second exception is about CFSP decisions providing restrictive measures against natural or legal persons.

Both exceptions are laid down in Article 24(1) TEU, according to which the Court has jurisdiction 'to monitor compliance with Article 40 of this Treaty and to review the legality of certain decisions as provided for by the second paragraph of Article 275 of the Treaty on the Functioning of the European Union'. The latter provision elaborates further:

.... the Court shall have jurisdiction to monitor compliance with Article 40 of the Treaty on European Union and to rule on proceedings, brought in accordance with the conditions laid down in the fourth paragraph of Article 263 of this Treaty, reviewing the legality of decisions providing for restrictive measures against natural or legal persons adopted by the Council on the basis of Chapter 2 of Title V of the Treaty on European Union.

The first exception, that is monitoring compliance with Article 40 TEU, is of a constitutional character. It aims to ensure that the procedural rules set out, on the one hand, in Title V TEU governing CFSP, and, on the other hand, the TFEU governing all other aspect of the EU's external action are complied with. Given that these rules differ considerable in terms of the applicable decision-making procedure and the ensuing input of the Union's institutions, Article 40 TEU seeks to ensure that a measure that ought to be adopted under CFSP rules is

\footnotetext{
24 See Case T-14/98 Hautala v Council EU:T:1999:157 paras 41-42, relying on Case T-174/95 Svenska Journalistförbundet $v$ Council EU:T:1998:127 paras 81-83. For the exceptions aiming to protect, amongst others, public security, defence and military matters and international relations, see art 4(1) Regulation 1049/2001 of the European Parliament and of the Council regarding public access to European Parliament, Council, and Commission documents [2001] OJ L145/43. See D Curtin, 'Official Secrets and the Negotiation of International Agreements: Is the EU Executive Unbound?' (2013) 50 CMLRev 423; and P Leino, 'The Principle of Transparency in EU External Relations - Does Diplomatic Secrecy Stand a Chance of Surviving the Age of Twittter?' in M Cremona (ed), Structural Principles in EU External Relations Law (Hart Publishing, forthcoming).
} 
not adopted pursuant to TFEU provisions, and vice versa. In doing so, it protects the distinct legal features of CFSP and the other external policies of the Union, as well as the underlying powers of the institutions conferred by primary law. Viewed from this angle, the principle enshrined in Article 40 TEU is tied in with the principle of institutional balance laid down in Article 13(2) TEU, according to which '[e]ach institution shall act within the limits of the powers conferred on it in the Treaties, and in conformity with the procedures, conditions and objectives set out in in them'. ${ }^{25}$

By endowing the Court with the jurisdiction to monitor compliance with Article 40 TEU, Articles 24(1) paragraph 2 TEU and 275 TFEU do not bestow a new power. Instead, they acknowledge an existing power, given that it is for the Court of Justice to ascertain whether an EU measure is adopted under the appropriate rules and procedures, as these are laid down in primary law. After all, even under the previous constitutional arrangements, the delimitation between the pillars was part of the Court's jurisdiction. ${ }^{26}$

The second exception from the CFSP exclusion is about the protection of fundamental rights in general, and the principle of effective judicial protection in particular. It was added in primary law by the Lisbon Treaty in the light of the proliferation of smart sanctions, that is measures targeting specific individuals or groups of persons or legal entities, as opposed to entire countries. As their target is narrower, their aim is to minimize the economic and other consequences that they may have for the wider population of a third country. They appeared for the first time in the early 1990s and have become popular following the $9 / 11$ terrorist attacks. ${ }^{27}$ In the EU context, smart

25 On the principle of institutional balance, see for instance Case C-63/12 Commission $v$ Parliament EU:C:2013:752 at para 73 and Case C-73/14 Council v Commission (re: ITLOS) EU: C:2015:663 at para 61. See C Hillion, 'Conferral, Cooperation and Balance in the Institutional Framework of the EU External Action' in M Cremona (ed), Structural Principles in EU External Relations Law (Hart Publishing, forthcoming).

${ }^{26}$ On the pre-Lisbon dividing line between the first (EC) and third (PJCCJ) pillars, see Case C-170/96 Commission v Council (Airport Transit Visa) ECLI:EU:C:1998:219, Case C-176/03 Commission v Council (criminal sanctions for environmental violations) ECLI:EU:C:2005:542, Joined Cases C-317/04 and C-318/04 Parliament v Council (EU-USA Passenger Name Record Agreement) ECLI:EU:C:2006:346, Case C-440/05 Commission v Council (criminal sanctions for ship-sourced pollution) ECLI:EU:C:2007:625. On the pre-Lisbon dividing line between the first pillar (in particular development cooperation) and CFSP, see Case C-91/05 Commission $v$ Council (Small Arms and Light Weapons) ECLI:EU:C:2008:288 - this is the only case where the Court held that ex art 47 TEU had been violated. The issue was also raised in T-349/99 Miscovic and Karic (about whether a CFSP measure banning certain persons from entering the EU territory should have been adopted under EC powers on free movement of persons), but the case was removed from the registry.

27 See, amongst others, I Cameron (ed), EU Sanctions: Law and Policy Issues Concerning Restrictive Measures (Intersentia 2013); E Cannizzaro, 'The EU Antiterrorist Sanctions' in P Eeckhout and M Lopez-Escudero (eds), The European Union's External Action in Times of Crisis (Hart Publishing 2016) 324; D Cortright and GA Lopez (eds), Smart Sanctions: Targeting Economic Statecraft (Rowman and Littlefield 2002); and M Eriksson, Targeting Peace: Understanding UN and EU Smart Sanctions (Routledge 2016). 
sanctions may take two forms: they may be of an economic nature (for instance, freezing assets of persons suspected of financing international terrorism), in which case they are implemented by means of EU legislation, or they may have a clearer security dimension (for instance, an arms embargo or a ban on the entry of individuals in the EU's territory) in which case they are imposed pursuant to a CFSP instrument only. It is the latter that constitutes the subject matter of the second exception from the CFSP exclusion under Articles 24(1) paragraph 2 TEU and 275 TFEU.

It follows from the above that the primary rules on the Court's jurisdiction in CFSP reflect the constitutional ambivalence that characterizes the position of this policy in the Union's overall structure. The CFSP exclusion and the two exceptions laid down in the Treaties raise two questions. First, what is the scope of the exclusion and where does its outer limit lies? Secondly, what is the scope of the two exceptions? The following sections will address these questions in turn, with reference to the Court's recent case law.

\section{THE SCOPE OF THE CFSP EXCLUSION}

Recent case law suggests that the Court of Justice has jurisdiction in the area of CFSP in two different contexts. The first context is procedural, and is about international agreements on CFSP issues and their consistency with the primary rules on the procedures that govern the negotiation and conclusion of international agreements. The Grand Chamber dealt with this question in Case C-658/11 Parliament v Council, a case about the EU-Mauritius Agreement on the transfer of persons suspected of piracy and arrested by EU staff in the context of the Union's Operation Atalanta off the coast of Somalia. ${ }^{28}$ It held that primary law (that is Article 218 TFEU) provides for 'a single procedure of general application concerning the negotiation and conclusion of international agreements which the European Union is competent to conclude in the fields of its activity, including the CFSP, except where the Treaties lay down special procedures'. ${ }^{29}$ This conclusion was confirmed subsequently in Case C-263/14 European Parliament $v$ Council (about the EU-Tanzania Transfer Agreement). ${ }^{30}$

The second context is substantive, and is about specific measures adopted by EU bodies in the context of CSDP operations and missions. In Case C-439/13 P Elitaliana,${ }^{31}$ the Court established its jurisdiction on the basis of the award of a

28 ECLI:EU:C:2014:2025. On the transfer agreements the EU concluded in the context of this operation, see D Thym, 'Transfer Agreements for Pirates Concluded by the EU: A Case Study on the Human Rights Accountability of the Common Security and Defence Policy' in P Koutrakos and A Skordas (eds), The Law and Practice of Piracy at Sea: European and International Perspectives (Hart Publishing 2014) 167.

29 Case C-658/11 European Parliament v Council, paras 52 and 71-74.

30 ECLI:EU:C:2016:435.

31 Case C-439/13 P Elitaliana SpA v Eulex Kosovo ECLI:EU:C:2015:753. 
public contract by the Head of the European Rule of Law Mission in Kosovo (EULEX Kosovo). This decision gave rise to expenditures which, in accordance with the Treaties ${ }^{32}$ and the EU's Financial Regulation applicable at the time, ${ }^{33}$ were charged to the EU's general budget. In the light of the above, the CFSP measure governing the mission provided that the rules and procedures applicable to the budget would also apply to the management of all the mission's expenditure. ${ }^{34}$ According to the judgment, the applicability of the EU's budget rules entailed the jurisdiction of the Court on the application of the EU's public procurement rules. The CFSP exclusion from its jurisdiction was, therefore, not relevant.

More recently, in Case C-455/14 P H, ${ }^{35}$ the Grand Chamber reached the same conclusion in relation to the review of a decision adopted by the Head of Mission of the European Union Police Mission (EUPM) in Bosnia and Herzegovina. The decision was about the deployment of an Italian magistrate, seconded to the mission, in a regional office in Bosnia and Herzegovina.

Like any other civilian mission carried out by the EU in the context of its security and defence policy, EUPM consists of staff seconded from the EU institutions and the Member States. A decision by the Head of Mission on allocation of the former at theatre level would fall within the jurisdiction of the Court of Justice pursuant to Article 270 TEU and the EU's Staff Regulations. ${ }^{36}$ The Court held that that should also be the case in relation to decisions about the staff seconded from the Member States. This was irrespective of certain differences between the two categories of staff (for instance, under the CFSP measures governing the Union's security and defence missions, including EUPM, the staff seconded from Member States are under the full command and the disciplinary powers of the Member States which also pay for their salaries and expenses). ${ }^{37}$

The jurisdiction of the Court was substantiated by two main arguments. The first was a common feature of the deployment of staff seconded from the EU institutions and the Member States: they were both subject to the same rules regarding the performance of their duties at theatre level, as they were both under command and control exercised by the Head of Mission. Whilst, therefore, they have 'an operational aspect falling within the CFSP', any

32 Art 41(2) TEU.

33 Art 4(2)(a) of Regulation 1605/2002 on the Financial Regulation applicable to the general budget of the European Communities [2010] OJ L 311/9.

${ }_{34}$ Art 16(2) Joint Action 2008/124/CFSP [2008] OJ L 42/92, amended by Council Dec 2011/ 752/CFSP [2011] OJ L 310/10.

35 Case C-455/14 P H ECLI:EU:C:2016:569.

36 Art 91 of Council Reg 259/68 [1968] OJ English Special Edition II p30, amended by Reg 1080/2010 [2010] OJ L 311/1. Art 270 TEU reads as follows: 'The Court of Justice of the European Union shall have jurisdiction in any dispute between the Union and its servants within the limits and under the conditions laid down in the Staff Regulations of Officials and the Conditions of Employment of other servants of the Union.'

37 For an overview of CSDP civilian missions, see P Koutrakos, The EU's Common Security and Defence Policy (Oxford Univesity Press 2013) Ch 6. 
decisions about staff allocation at theatre level 'also constitute, by their very essence, acts of staff management, just like all similar decisions adopted by the EU institutions in the exercise of their competences'. ${ }^{38}$ The second argument was about coherence: the Court held that, if its jurisdiction did not cover in toto a decision on staff allocation at theatre level concerning both staff members seconded by the EU institutions and the Member States, the decision on the former may be rendered irreconcilable with the interpretation given by the Court to the decision on the latter.

There is a thread that brings together the main rationale of the case law outlined in this section: having construed the exclusion of CFSP from its jurisdiction under Articles 24(1) TEU and 275 TFEU as a derogation from the rule of its general jurisdiction (Article 19 TEU), the Court interprets the provisions governing this exclusion narrowly. ${ }^{39}$ This approach to the interpretation of rules and exceptions is not novel. It is consistent with a thread that underpins other areas of EU law. In relation to the internal market, for instance, it is a constant that, while the fundamental freedoms are interpreted broadly, the derogations laid down in primary law are interpreted strictly. ${ }^{40}$ The terms, however, in which this rule-exception principle is couched in the case law examined in this section reflects the main perspective through which the Court is set to approach the question of its jurisdiction. It may well be argued that, in fact, it is its jurisdiction in CFSP that is exceptional, the rule being the CFSP exclusion laid down in Article 24(1) paragraph 2 TEU and Article 275 TFEU. ${ }^{41}$ Such an approach would be consistent with the distinct nature of CFSP in the Union's constitutional order, that is the first theme examined in Section II above. It would, therefore, reflect the logic of the exclusion and would suggest that the exceptional jurisdiction to rule on compliance with Article 40 TEU and the legality of CFSP decisions targeting natural and legal persons would be interpreted narrowly. This, however, was not the approach that the Court adopted. ${ }^{42}$ Instead, by placing the jurisdiction in CFSP against the principle of general jurisdiction under Article 19(1) TEU, the case law is couched in the language of integration. It, therefore, reflects

38 ECLI:EU:C:2016:569, para 54.

39 Case C-658/11 Parliament v Council para 70, Case C-439/13 P Elitaliana para 41, C-455/14 P $H$ para 40). This principle was followed by analogy in Case C-72/15 Rosneft ECLI:EU: C:2016:381, paras 74-75.

40 See, for instance, Case 41/74 Van Duyn ECLI:EU:C:1974:133 para 18, Case C-348/96 Calfa ECLI:EU:C:1999:6 para 23 and Case C-441/02 Commission v Germany ECLI:EU:C:2006:253 paras 32-35. For an analysis of the Court's approach to the exceptions from free movement, see P Koutrakos, N Nic Shuibhne and P Syrpis (eds), Exceptions from EU Free Movement Law: Derogation, Justification and Proportionality (Hart Publishing 2016).

41 See AG Kokott in her View in Opinion 2/13, ECLI:EU:C:2014:2475, para 89.

42 For an early observation that the Lisbon Treaty marked a shift of perspective, and suggested that the CFSP exclusion was, in fact, exceptional, see A Hinarejos, Judicial Control in the European Union: Reforming Jurisdiction in the Intergovernmental Pillars (Oxford University Press 2009) 150 . 
the second theme of CFSP law that was examined in Section II above, that is integration.

In making this choice about how to approach jurisdiction in CFSP, the case law produces outcomes that vary widely in terms of their fidelity to the spirit of the CFSP exclusion. Take, for instance, the judgments in the EU-Mauritius and EU-Tanzania cases. It was not in dispute that the primary rules on treatymaking, laid down in Article 218 TFEU, applied to the negotiation and conclusion of CFSP agreements. Each Agreement was concluded by the EU by means of a Council Decision to which it was annexed. This Decision was based on Article 37 TEU (referring to the CFSP substantive provision that covered its content), and Article 218(5) and (6) TFEU (referring to the procedure governing its adoption). Had the drafters of the Treaties wished to render the procedures governing CFSP treaty-making beyond the scope of the Court's jurisdiction, they would have included a specific provision in Title V TEU. They did not. Instead, they set out the applicable procedure beyond the CFSP framework, that is in Article 218 TFEU. Described by Dashwood as 'the procedural code' for treaty-making, ${ }^{43}$ these provisions govern the negotiation and conclusion of most international agreements ${ }^{44}$ and have been viewed by the Court as 'an autonomous and general provision of constitutional scope in that [Article 218 TFEU] confers specific powers on the EU institutions' and aims to 'establish ... a balance between those institutions' ${ }^{45}$ In both the EU-Mauritius and EU-Tanzania cases, the jurisdiction of the Court was about compliance with the procedural rules governing the Agreements, and did not extend to the substantive provisions of the Agreements themselves.

A different picture, however, emerges from the Court's willingness to affirm its jurisdiction on substantive issues pertaining to CFSP. On the surface, both cases outlined above appear to be about administrative measures of narrow scope (namely spending in Elitaliana and staff management in $H$ ). A closer look, however, at their specific context and the line of reasoning followed by the Court suggests not only substantial differences, but also a creeping expansionist approach to the question of jurisdiction. On the one hand, in Elitaliana, there was a crucial link between the CFSP context within which the dispute arose and the jurisdiction of the Court, namely the applicability of the Union's own rules governing its budget. As the contested decision was about a tender award, it was, in fact, about the application of EU public procurement rules. This link was expressly laid down in primary law (Article 41(2) TEU about operating expenditure of EU missions), the applicable CFSP measure (Joint Action 2008/124), and the EU's Financial Regulation,

\footnotetext{
43 A Dashwood, M Dougan, B Rodger, E Spaventa and D Wyatt, Wyatt and Dashwood's European Union Law (6th edn, Hart Publishing 2011) 936.

44 There are two areas where special rules apply: the conclusion of exchange rate and monetary agreements which is governed by art 219 TFEU, and the agreements concluded in the area of Common Commercial Policy in so far as 'special provisions' are provided for in art 207 TFEU.

45 Case C-425/13 Commission v Council ECLI:EU:C:2015:483, para 62.
} 
all of which provided a firm foundation for the non-applicability of the CFSP exclusion. ${ }^{46}$

On the other hand, such a link was absent in $H$. Instead, the Court's jurisdiction was affirmed in order to equate the status of staff seconded from Member States to that of EU staff. In doing so, however, the judgment engages in interpretative acrobatics, for instance by relying on issues of questionable relevance, such as the duty of all staff to abide by the missionspecific minimum security operating standards. ${ }^{47}$ It also makes a misconceived analogy with the status of national experts seconded to the European Defence Agency (EDA) and the European External Action Service (EEAS) which is subject to its jurisdiction. In the case of these bodies, the legal rules governing their functioning refer specifically to the Court's jurisdiction. ${ }^{48}$ This was a choice, in other words, that the EU institutions made in order to deal with disputes that may arise from the employment of seconded staff. It is far from clear how the express conferment of jurisdiction in certain cases might be relied upon in order to read the same outcome in the silence of the applicable secondary rules in other, different cases. After all, neither EDA nor EEAS may be considered analogous to a CSDP mission. The former are permanent administrative bodies whose work pertains to the CFSP but whose function is to support policy-formation as a matter of course. The latter are about specific initiatives undertaken ad hoc pursuant to the political will of the Council and relying on the deployment of staff in order to reach on the ground specific operational goals. To draw an analogy between these different bodies is to use a strikingly broad brush in order to establish jurisdiction in areas where the drafters of the Treaties require that the Court tread carefully.

In essence, the Court's reasoning in $H$ defined the scope of the CFSP exclusion on the basis of a fundamental distinction: staff management decisions fall within the scope of its jurisdiction, as they are viewed 'just like all similar decisions adopted by the EU institutions in the exercise of their competences' ${ }^{49}$ whereas operational decisions do not. It is this distinction that lies at the heart of the judgment. It appears to be similar to the broad theory that the Commission had put forward in its submissions. The latter had suggested that only CFSP acts expressing the sovereign foreign policy of the Union (analogous to actes de gouvernment) would be excluded from the Court's jurisdiction, whereas acts implementing that policy would not be.

The Court, however, did not articulate the distinction between operational and staff management decisions as a general test that would determine the scope of Articles 24(1) TEU and 275 TFEU. It set it out, instead, in the

\footnotetext{
46 In the Order under appeal, the General Court had dismissed the action as inadmissible on a different matter and without considering the question of jurisdiction on CFSP provisions (T-213/12 EU:T:2013:292).

${ }_{47}$ Art 7(4) of Dec 2009/906/CFSP, mentioned in para 53 of the judgment.

${ }^{48}$ Art 11(3)(b). $\quad{ }_{49}$ Case C-455/14 P H ECLI:EU:C:2016:569, para 54.
} 
context of the contested decision. It is noteworthy, however, that even the Commission had argued that the action was inadmissible, because, far from giving effect to an act of implementation, a decision by the Head of Mission redeploying a member of staff seconded from a Member State was of an operational nature. In its judgment, whilst it did not endorse the Commission's argument, the Court went even farther in certain respects: it held that it would have jurisdiction even over a measure that was both of an operational character and about staff management.

The administrative issues that pertained to the dispute in $H$ may appear to be devoid of the political sensitivity that characterizes the conduct of foreign, security policy and defence. As such, they may be considered uncontroversial. This view, however, amounts to a generalization that should be avoided. What appears to be an administrative or management issue may also reflect substantive operational choices which are important for the conduct of CFSP on the ground. There is, furthermore, no distinction between low and high politics inherent in the CFSP exclusion - to introduce it in order to substantiate an expansive jurisdiction for the Court sits uneasily with the ratio of the exclusion itself. This is all the more so given the broad-brush line of reasoning that appears in the judgment in $H$.

In particular, the conclusion reached by the Court in $H$ is problematic for both legal and practical reasons. First, it relies upon a distinction that has no foundation in primary law. Reading into Articles 24(1) TEU and 275 TFEU a criterion for determining the outer limits of their scope is tantamount to narrowing down their application in ways that the drafters of the Treaties did not envisage. This point was made by Advocate General Wahl who, in his Opinion, drew attention to the distinction between the broad wording of the CFSP exclusion in Articles 24(1) TEU and 275 TFEU and the narrow wording of another primary provision restricting the role of the Court of Justice in the Area of Freedom, Security, and Justice (AFSJ), that is Article 276 TFEU. ${ }^{50}$ Advocate General Wahl, then, argued that, 'had the drafters of the Treaties had the intention of introducing an exception of a more limited scope to the CJEU's jurisdiction - essentially confining it to the acts of sovereign foreign policy - they would have drafted Articles 24(1) TEI and 275 TFEU differently'. 51

Secondly, the criterion upon which the Court relied is difficult to apply in practice. This point was also made by Advocate General Wahl in his thoughtful Opinion where he argued that, 'given the nature and functioning of CFSP', acts of implementation 'may often be of great political significance

50 Art 276 TFEU provides that the Court has no jurisdiction 'in exercising its powers regarding the $[\mathrm{AFSJ}]$ provisions ... to review the validity or proportionality of operations carried out by the police or other law-enforcement services of the Member States or the exercise of the responsibilities incumbent upon Member States with regard to the maintenance of law and order and the safeguarding of internal security'.

${ }_{51}$ Opinion in Case C-455/14 H P ECLI:EU:C:2016:212, para 64. 
and sensitivity', hence making it 'difficult to determine the administrative element of the act without taking into account the underlying foreign policy objective pursued' ${ }^{52}$ The dispute in $H$ was about a decision of the Head of Mission regarding the deployment of a magistrate from one place to another. If such a decision were not operational in nature, it would be difficult to envisage what type of decision would be. In fact, the judgment uses the term 'allocation of human resources assigned to [the Mission] by the Member States and the EU institutions'. ${ }^{53}$ Leaving aside the use of management jargon that should be avoided at all cost in any context, let alone by the Court of Justice, these words reflect the broader tenor of the judgment that ends up downgrading the operational, and hence sensitive, nature of staff decisions taken in CSDP missions in order to assimilate them to management measures. Finally, another practical difficulty raised by the judgment in $H$ has to do with substantive rules that should now govern the applicant's legal position. Which set of rules will the General Court apply? After all, the EU's staff regulations are not applicable, given that she is seconded from a Member State. ${ }^{54}$

It is not, however, only the conclusion reached by the judgment in $H$ that is problematic. The line of reasoning is also unconvincing. The Court justified its jurisdiction to rule on a Head of Mission's decision regarding the deployment of staff seconded from a Member State by reference to its jurisdiction to rule on a decision regarding the deployment of EU-seconded staff. As the Head of a Mission might well take a decision about both types of staff, 'irreconcilable' differences would emerge unless the Court's jurisdiction extended to both. It is not the first time that, in order to extend its jurisdiction, the Court has relied upon this type of argument that purports to protect the Union's legal order from potential incoherence in the future. It did so in the context of mixed agreements. These are international agreements concluded by both the EU and the Member States because their content falls within the competence of both. The question arose early on about whether such agreements would fall within the jurisdiction of the Court, in particular as far as their provisions covered by national competence were concerned. The case law dealing with this issue is not burdened by clarity, and its analysis is beyond the scope of this article. ${ }^{55}$ Suffice it to point out that, gradually, the Court interpreted the scope of its jurisdiction widely by following a line of reasoning that reminds one of the judgment in $H$. A case in point is the judgment in Case C-53/96 Hermès where it was held that the interpretation of a provision of the Agreement on Trade-Related Aspects of Intellectual Property Rights (TRIPS), that is a mixed agreement, regarding provisional measures fell

52 Opinion in Case C-455/14 H P ECLI:EU:C:2016:212, para 62.

53 Case C-455/14 P H ECLI:EU:C:2016:569, para 54.

54 I am grateful to Joni Heliskoski for raising this point.

55 See P Koutrakos, 'The Interpretation of Mixed Agreements' in C Hillion and P Koutrakos (eds), Mixed Agreements Revisited: The EU and Its Member States in the World (Hart Publishing 2010) 116. 
within the scope of the Court's jurisdiction even in a dispute about a national trademark. ${ }^{56}$ This was because the TRIPS provision in question was also applicable to EU secondary legislation on trademarks, and, therefore, 'it is clearly in the Community interest that, in order to forestall future differences of interpretation, that provision should be interpreted uniformly, whatever the circumstances in which it is to apply'. ${ }^{57}$ This was, in essence, the logic underpinning the judgment in $H$ : if the Court had jurisdiction to interpret a decision of the Head of Mission in certain respects (as regards EU-seconded staff), its jurisdiction should extend to the entirety of the decision (as regards staff seconded from the Member States too), for, otherwise, 'irreconcilable' differences of interpretation might emerge.

This approach is less convincing in the context of CFSP than it was in the context of mixed agreements almost 20 years ago. It is not for the Court to ensure the coherence of administrative decisions adopted by the CSDP personnel on the ground. And it cannot be for the Court to superimpose its own idea of coherence on the administrative structures designed by the Member States in foreign policy, security, and defence. Were such differences to emerge, it would be for the Union's organs (the Head of Mission, the Civilian Operation Commander, the Political and Security Committee, and, ultimately, the High Representative) to address them. By using this interpretative device in order to extend the scope of its jurisdiction, the Court of Justice usurps a power that the institutional structure of the Treaties do not bestow upon it. Its approach also runs counter to the logic of the system of judicial review established in primary law in relation to CFSP. In the words of Advocate General Wahl in $H$ : '[t]hat system is, in fact, the result of a conscious choice made by the drafters of the Treaties, which decided not to grant the CJEU general and absolute jurisdiction over the whole of the EU Treaties. The Court may not, accordingly, interpret the rules set out in the Treaties to widen its jurisdiction beyond the letter of those rules or to create new remedies not provided therein' .58

The analysis so far of the case law on the scope of the CFSP exclusion illustrates an approach couched in the language of integration that underestimates the nuances of the conduct of CFSP and marginalizes the distinct position of this policy in the Union's constitutional order. Two questions arise about the specific implications of this case law. First, would the broad approach to the procedural dimension of CFSP agreements also apply to their substance? In other words, does the jurisdiction to ensure compliance with the procedural rules laid down in Article 218 TFEU also extend to the substance of CFSP agreements and their compliance with substantive EU law? This question has not been addressed so far, as the judgments in Case C-658/11 Parliament $v$ Council (EU-Mauritius) ${ }^{59}$ and

\footnotetext{
56 ECLI:EU:C:1998:292.

58 Opinion in Case C-455/14 P ECLI:EU:C:2016:212, para 49.

59 ECLI:EU:C:2014:2025.
} 
Case C-263/14 European Parliament v Council (EU-Tanzania) were confined to procedural issues and the choice of legal basis. The answer to this question is not clear-cut. On the one hand, the procedural legal basis for the negotiation and conclusion of CFSP agreements is laid down in Article 218 TFEU, a provision that is subject to the Court's jurisdiction. Furthermore, such agreements are not expressly excluded from the a priori jurisdiction of the Court under Article 218 (11) TFEU to rule on the compatibility of international agreements with the Treaties. ${ }^{60}$ If the latter was accepted, it would be difficult to rule out the ex post facto jurisdiction in the context of a preliminary reference or an annulment action. ${ }^{61}$ On the other hand, to extend the jurisdiction to CFSP international agreements may not sit comfortably with the wording and underlying logic of the CFSP exclusion in Article 24(1) paragraph 2 TEU and Article 275 TFEU. Whilst concluded under Article 218 TFEU, CFSP international agreements are also concluded under Article 37 TEU: it is the latter that provides the substantive legal basis for the conclusion of such agreements and which clearly falls beyond the scope of the Court's jurisdiction pursuant to the CFSP exclusion. A balance could be struck by construing the jurisdiction of the Court narrowly: this approach would confine judicial review of CFSP agreements to procedural questions about their negotiation and conclusion. This view would, therefore, read into Article 218(11) TFEU a limitation which, whilst not expressly set out therein, would reconcile this provision with Article 24(1) paragraph 2 and Article 275 TFEU. It would also, however, reduce the significance of the Court's a priori jurisdiction considerably.

The second question about the Court's broad approach to the scope of the CFSP exclusion is whether it would also extend to the two exceptions laid down in Articles 24(1) paragraph 2 TEU and 275 TFEU. This will be answered in the following sections which deal, in turn, with the substantive and procedural aspects of these provisions.

\section{THE SUBSTANTIVE SCOPE OF THE EXCEPTIONS FROM THE CFSP EXCLUSION}

It is recalled that the first exception from the CFSP exclusion from the Court's jurisdiction is about compliance with Article 40 TEU. It aims to ensure that the procedures and institutional powers laid down in the Treaties are complied with: in other words, a CFSP measure should not be adopted pursuant to non-CFSP provisions, and vice versa. As for the second exception, it is about CFSP decisions imposing restrictive measures on natural or legal persons. Whilst the definition of this term is not provided in Article 24(1) paragraph 2 TEU,

\footnotetext{
${ }^{60}$ For an analysis of this procedure, see P Eeckhout, EU External Relations Law (2nd edn, Oxford University Press 2011) 268-74 and P Koutrakos, EU International Relations Law (2nd edn, Hart Publishing 2015) 230-5.

61 See Eeckhout (n 60) 498 who argues that the interpretation and application of CFSP agreements fall within the scope of the Court's jurisdiction.
} 
or Article 275 TFEU, its implications are considerable: the broader its scope, the narrower the CFSP exclusion from the Court's jurisdiction and the broader the role of the Court of Justice in the area.

There is no case law since the entry into force of the Treaty of Lisbon in which a violation of Article 40 TEU has been affirmed. ${ }^{62}$ In fact, whilst questions have been raised before the Court about either the input of the Parliament in the adoption of a CFSP Agreement, ${ }^{63}$ or the scope of the CFSP dimension of an agreement concluded under CFSP rules, ${ }^{64}$ there has only been one case where the issue of compliance with Article 40 has been raised directly. This was in Rosneft, ${ }^{65}$ a case about sanctions in which the Court also defined the term 'CFSP decisions providing for restrictive measures against natural or legal persons'.

In order to appreciate the legal issues underpinning the construction of these exceptions and which were raised in Rosneft, it is worth outlining the procedure pursuant to which the EU imposes restrictive measures. It entails two stages. The first is about the determination by the Council of the political will of the Union to impose such measures. This is expressed in a CFSP measure adopted unanimously by the Council in accordance with the provisions governing the CFSP (Chapter 2, Title V TEU). Once this measure has been adopted, the second stage of the procedure is triggered: the Council adopts by qualified majority 'the necessary measures' setting out in detail the restrictions envisaged in the prior CFSP measure (Article 215 TFEU).

This two-stage procedure aims to bring together the foreign policy and economic dimension of restrictive measures and the distinct sets of EU rules that govern them. As such, it is not novel, and has its origin in the Maastricht Treaty. ${ }^{66}$ The Lisbon Treaty, however, provided, for the first time, an express legal basis for the adoption of restrictive measures against natural or legal persons and groups or non-State entities following the adoption of a CFSP decision to that effect (Article 215(2) TFEU).

The two-stage procedure outlined above is relied upon in cases where the restrictive measures that the EU decides to impose pertain to the areas covered by the Union's competence pursuant to the TFEU provisions. The Union, however, may also impose restrictive measures that are not covered

\footnotetext{
${ }_{62}^{62}$ For the pre-Lisbon period, see $\mathrm{n} 26$.

${ }^{63}$ C-658/11 European Parliament $v$ Council (EU-Mauritius Transfer Agreement) EU: C:2014:2025.

${ }^{64}$ C-263/14 European Parliament $v$ Council (EU-Tanzania Transfer Agreement) EU: C:2016:435.

${ }^{65}$ Case C-72/15 Rosneft ECLI:EU:C:2016:381. It had also been raised by Advocate General Wahl in his Opinion in $H$, where he argued that the term 'restrictive measures' should not cover all EU acts adversely affecting the interests of individuals; instead, they should refer to sanctions against individuals decided and implemented in the context of the CFSP (Case C-455/14 P $H$ ECLI:EU:C:2016:212 at paras 73-81. The Court did not deal with this issue in its judgment.).

${ }^{66}$ For an analysis of the original formulation of, as well as the precursors to the two-stage procedure that is now applicable, see P Koutrakos, Trade, Foreign Policy and Defence in EU Constitutional Law (Hart Publishing 2001) chs 3-4.
} 
by the TFEU provisions and, therefore do not require recourse to the Article 215 procedure. Such measures include, amongst others, restrictions on the entry and transit of persons, or arms embargoes.

The judgment in Rosneft was about restrictive measures imposed by the EU following the annexation of Crimea in March 2014 and in the light of Russia's role in the destabilization of the security situation in Ukraine. The Union imposed a set of restrictive measures the scope and intensity of which expanded gradually. In particular, Council Decision 2014/512/CFSP67 and accompanying Regulation $833 / 2014^{68}$ imposed restrictions on certain financial transactions and on the access of some Russian entities to EU capital markets, and on the export of some goods, technology and services required for oil transactions. Rosneft is a company specializing in the oil and gas sectors. It is incorporated in Russia and the majority of its capital owned by a body owned by the Russian State. It challenged the above measures both before the High Court in England and Wales (where it also challenged UK implementing measures) and the General Court of the EU. ${ }^{69}$

The judgment dealt with both exceptions from the CFSP exclusion. The significance of these issues was illustrated by the fact that the judgment was rendered by the Grand Chamber. In relation to the first exception, that is compliance with Article 40 TEU, the Court held that the CFSP measure targeting Rosneft was correctly adopted pursuant to CFSP rules, ${ }^{70}$ even though its content was detailed and reproduced in the contested Regulation. Given, on the one hand, the technical nature of the field, and, on the other hand, the wide scope of CFSP aims and objectives in the Treaties, ${ }^{71}$ 'it may prove appropriate for the Council to use detailed wording when establishing restrictive measures' in a CFSP decision, without, therefore, impinging on the different procedure governing the implementing measure under Article 215 TFEU. ${ }^{72}$ The Court also held that the contested Decision had not amounted to a legislative act (which the EU is prevented from adopting in the CFSP field pursuant to Articles 24(1) subparagraph 2 and 31 TEU): as the division of institutional powers in CFSP decision-making differs from that governing the adoption of legislative acts under TFEU rules, the application of the former suggested that the contested Decision was not a legislative measure.

The analysis of the issue of compliance with Article 40 TEU in Rosneft illustrates a generous approach to the decision-making institutions. The broad

${ }^{67}$ Dec 2014/51/2/CFSP [2014] OJ L 229/13, amended by Dec 2014/659/CFSP [2014] OJ L 271/54 (which referred to Rosneft expressly in Annex III), and Decision 872/CFSP [2014] OJ L 349/58 (and subsequently by Dec 2015/971 [2015] OJ L 157/50, Dec 2015/1764/CFSP [2015] OJ L 257/42, Dec 2015/2431/CFSP [2015] OJ L 334/22, Dec 2016/1071/CFSP [2016] OJ L 178/ 21, Dec 2016/2315/CFSP [2016] OJ L 345/65).

68 Regulation 833/2014 [2014] OJ L 229/1, amended by Council Regulation 960/2014 [2014] OJ L 246/59 (which referred to Rosneft expressly in Annex III), and subsequently by Reg 1290/2014 [2014] OJ L 349/20, Reg.2015/1797 [2015] OJ L 263/10. 69 T-715/14 Rosneft (pending).

70 Art 29 TEU.

72 Case C-72/15 Rosneft ECLI:EU:C:2016:381, para 90. 
discretion that the latter enjoy in CFSP, along with the broad scope of the policy, suggest considerable leeway in policymaking. They also suggest a corresponding reluctance on behalf of the Court to interfere with the substance of the choices made by the institutions. This is illustrated by the light touch review of the content of the contested Decision in the judgment. It is also reflected by the formalist and somewhat circular response to the legislative act claim: does reliance upon the CFSP procedures really suggest ipso facto that the measure adopted thereunder is not a legislative act? Cremona argues that the Court approaches Article 40 TEU in a hands-off manner: once a CFSP legal basis is chosen by the EU institutions, it is difficult to challenge. ${ }^{73}$ In fact, the judgment in Rosneft does not introduce strict criteria that the content of EU measures must meet in order to justify their adoption under CFSP rules.

As for the second exception from the CFSP exclusion, it does not cover measures the scope of which is determined by reference to objective criteria and which, rather than targeting identified natural or legal persons, are applicable generally. ${ }^{74}$ The provisions, therefore, of the contested Decision that subjected certain activities to restrictive measures would not be covered by the Court's jurisdiction, even if only a handful of legal persons were in a position to carry out the activities in question. On the other hand, the provisions of the contested Decision that refer expressly to specific legal persons constitute measures targeting the latter and, as such, would fall within the scope of the Court's jurisdiction. It is 'the individual nature' of such CFSP restrictive measures that trigger access to the Union's Courts. ${ }^{75}$

In Rosneft, the Court reached different conclusions in relation to the two exceptions from the CFSP exclusion: does this suggest a different approach, more generous when it comes to choosing a CFSP legal basis, but more rigorous when it comes to CFSP restrictive measures on individuals? In order to answer this question, we should revisit the distinction between the two exceptions made in Section II above. On the one hand, compliance with Article $40 \mathrm{TEU}$ is about the constitutional position of CFSP in the EU's legal order: the rules and procedures laid down in Title V TEU differ from those governing all the other external policies, as they reflect the different logic on the basis of which CFSP is organized. In other words, compliance with Article $40 \mathrm{TEU}$ is about ensuring that CFSP rules have been relied upon properly and not in order to usurp powers allocated to EU institutions under non-CFSP rules. Put differently, this is about the first choice that decisionmakers need to make, as it is about deciding upon which set of primary rules to rely. On the other hand, the adoption of CFSP decisions providing

73 M Cremona, 'The CFSP-CSDP in the Constitutional Architecture of the EU' in S Blockmans and P Koutrakos (eds), Research Handbook on CFSP/CSDP (Elgar Publishing, forthcoming).

74 Case C-72/15 Rosneft ECLI:EU:C:2016:381, para 97. See also paras 103-104.

75 ibid, para 103 . 
restrictive measures against natural or legal persons has an impact on the human rights of these persons. The Court's jurisdiction extends to the first issue because it is for the Court, as a constitutional adjudicator, to rule on the coexistence of the different sets of rules that govern what the Union does. In the second case, however, the Court's jurisdiction is triggered once the Union has acted pursuant to CFSP and without calling into question the reliance upon CFSP powers. This is, in other words, about the implications of the first choice that decision-makers have made: once reliance on CFSP has been decided, the protection of the human rights of the targeted persons is monitored by extending the jurisdiction of the Court of Justice.

Viewed from the above angle, there is no contradiction in Rosneft: the EU institutions were given leeway to decide how to act pursuant to CFSP rules; once, however, they acted by targeting private and legal persons, the jurisdiction of the Court of Justice would be triggered. The conclusion reached by the Court should also be examined in its proper factual and legal context. The measures at issue in Rosneft were not as controversial as they might be, given that they mentioned expressly a number of entities, including the applicant, in an Annex and, by reference, in a number of provisions. Would they still fall within the scope of Article 275 TFEU if they merely defined in a specific manner certain criteria that only a very small number of entities could meet, even though the latter were not mentioned? The Court in Rosneft held that, 'by establishing the criteria ..., allowing the identification of Rosneft, and by naming that company in Annex III to that decision, the Council adopted restrictive measures against the legal person concerned' ${ }^{76}$ These issues may be explored further in the future, as the interpretation of the scope of restrictive measures against natural or legal persons under Article 275 TFEU is not settled. ${ }^{77}$

\section{THE PROCEDURAL SCOPE OF THE EXCEPTIONS}

Having explored the interpretation of the substantive aspects of the two exceptions from the CFSP exclusion from the Court's jurisdiction, the question that is raised is about the procedural mechanisms on the basis of which this jurisdiction may be exercised. This was addressed in Rosneft. It is worth recalling that, in the EU legal order, the review of legality of acts adopted by the Union's institutions is decentralized. Private parties may bring proceedings directly before the General Court and, on appeal, the European Court of Justice on the substantive grounds laid down in Article 263 subparagraph 2 TFEU, provided that they meet strict locus standi conditions (Article 263 subparagraph 4 TFEU). The legality of EU acts, however, may

\footnotetext{
76 ibid, para 104.

77 The definition of such measures is also the subject matter of ongoing litigation: Joined Cases T-735/13 and T-799/14 Gazprom Neft OAO v Council and Case T-160/13 Bank Mellat v Council.
} 
also be challenged before domestic courts. ${ }^{78}$ Given that the latter are precluded from invalidating EU law, ${ }^{79}$ they must make a preliminary reference to the Court of Justice under Article 267 TFEU if they have doubts about the legality of an EU act. These two procedural avenues, namely annulment actions and preliminary references, are viewed as intrinsically linked and amount to 'a complete system of legal remedies and procedures designed to ensure judicial review of the legality of acts of the institutions'. 80

In the light of the above, the question is raised whether the limited jurisdiction of the Court in CFSP matters may be applied in actions that are brought before the Court of Justice both directly, under Article 263 TFEU, and indirectly, under Article 267 TFEU. As far as the first exception to the CFSP exclusion is concerned, that is monitoring the application of Article 40 TEU, the Treaties are silent. Neither Article 24(1) TEU, nor Article 275 TFEU refer to a specific procedural mechanism. Things are, however, different in relation to CFSP decisions providing restrictive measures against natural or legal persons: Article 24(1) TEU refers to the jurisdiction 'to review the legality of certain decisions as provided for by the second paragraph of Article 275 [TFEU]'. The latter states, in turn, that the Court has jurisdiction 'to rule on proceedings, brought in accordance with the conditions laid down in the fourth paragraph of Article 263 of this Treaty, reviewing the legality' of CFSP decisions providing for restrictive measures against natural or legal persons. Does the silence of the above provisions suggest that a claim for a violation of Article 40 TEU could be brought before the Court of Justice under either the preliminary reference or the annulment procedure? And does the reference to annulment actions only in relation to CFSP measures targeting private parties suggest that the Court would not have jurisdiction in preliminary references?

The Grand Chamber answered these questions in the affirmative. In relation to Article $40 \mathrm{TEU}$, it held that the absence of a reference to 'any particular means by which such judicial monitoring is to be carried out' suggested that the general jurisdiction of the Court, under Article 19 TEU, would apply. ${ }^{81}$ Given that Article 19(3)(b) TEU referred specifically to its jurisdiction to give preliminary rulings, that also covered questions by national courts on the validity of CFSP measures under Article 40 TEU.

More controversially, the Court reached the same conclusion for the legality of CFSP decisions providing restrictive measures to natural and legal persons.

78 Provided that the applicant does not have locus standi before the General Court under art 263 para 4 TFEU: Case C-188/92 TWD ECLI:EU:C:1994:90.

79 Case 314/85 Foto-Frost ECLI:EU:C:1987:452.

${ }^{80}$ Case C-50/00 P UPA ECLI:EU:C:2002:462, para 40. See also C-583/11 P Inuit ECLI:EU: C:2013:625, para 92. See A Arnull, 'Judicial Dialogue in the European Union' in J Dickson and P Eleftheriadis (eds), Philosophical Foundations of European Union Law (Oxford University Press 2012) 109 and K Lenaerts, 'The Rule of Law and the Coherence of the Judicial System of the European Union' (2007) 44 CMLRev 1625.

${ }^{81}$ Case C-72/15 Rosneft ECLI:EU:C:2016:381, para 62. 
This was substantiated on a number of arguments. The first argument was contextual: it was about the 'complementary' nature of the procedures governing annulment actions and preliminary references, and the ensuing establishment of 'a complete system of legal remedies and procedures designed to ensure judicial review of the legality of European Union acts' which has been 'entrusted ... to the Courts of the European Union' ${ }^{82}$ As it is 'inherent in that complete system' that the validity of an EU measure may be raised before a domestic court, and given that a request for a preliminary ruling on such a matter constitutes a means of reviewing the legality of EU acts, 'that essential characteristic of the system for judicial protection in the European Union extends to the review of the legality' of CFSP decisions imposing restrictive measures on natural or legal persons. ${ }^{83}$

The second argument was textual: the Court held that the Treaties provided no indication that preliminary references should be excluded from its exceptional jurisdiction to review CFSP measures. The express mention of Article 263 TFEU in Article 275 TFEU was not considered relevant, as the latter provision was referred to in Article 24(1) second subparagraph TEU 'in order to determine not the type of procedure under which the Court may review the legality of certain decisions, but rather the type of decisions whose legality may be reviewed by the Court, within any procedure that has as its aim such review of legality'. ${ }^{84}$

The third argument was about the central role of the Member States in CFSP measures. Member States are partly responsible for the implementation of restrictive measures and they are under a duty to ensure that their policies conform with the EU's position enshrined in CFSP decisions. ${ }^{85}$ Access, therefore, to judicial review of such decisions 'is indispensable where those decisions prescribe the adoption of restrictive measures against natural or legal persons', and a reference for a preliminary ruling, 'plays an essential part in ensuring effective judicial protection' ${ }^{86}$

The fourth argument was about general principles. On the one hand, the Court referred to the rule of law, that is one of the EU's founding values under Article $2 \mathrm{TEU}$, one of the common provisions of the TEU. The rule of law is also amongst the principles that guide the Union's external action under Article $21 \mathrm{TEU}$, the latter provision applying to the CFSP too (Article $23 \mathrm{TEU}$ ). On the other hand, the principle of effective judicial protection is enshrined in Article 47 of the Charter ${ }^{87}$ and is essential for the rule of law. While it acknowledged that that provision could not confer jurisdiction where primary

${ }^{82}$ Case C-72/15 Rosneft ECLI:EU:C:2016:381, para 66.

84 ibid, para 70.

83 ibid, paras 67 and 69.

${ }^{86}$ Case C-72/15 Rosneft ECLI:EU:C:2016:381, para 71.

87 Art 47 para 1 of the Charter reads as follows: 'Everyone whose rights and freedoms guaranteed by the law of the Union are violated has the right to an effective remedy before a tribunal in compliance with the conditions laid down in this Article.' 
law excludes it, the Court held that 'the principle of effective judicial protection nonetheless implies that that exclusion of the Court's jurisdiction in the field of the CFSP should be interpreted strictly'. ${ }^{88}$

The fifth argument was about the general jurisdiction of the Court under Article 19(1) TEU: a strict interpretation of the exceptional jurisdiction conferred by Article 275 TFEU, to which Article 24(1) TEU refers, would be contrary to the objectives of Article 19(1) TEU, as well as the principle of effective judicial protection.

The final argument was about national courts. Their role was dismissed as contrary to 'the necessary coherence of the system of judicial protection' which requires that only the Court of Justice should have jurisdiction to declare EU acts void, and the essential objective of the preliminary reference procedure, that is to ensure the uniform application of EU law by domestic courts. ${ }^{89}$

The judgment in Rosneft followed the thread that had emerged in $H$ and extended it both boldly and considerably. The perspective of the judgment is distinctly integrationist. For instance, the starting point of the Court's analysis is not the logic of the CFSP exclusion or the distinct position of the CFSP in the Union's constitutional order. Instead, the judgment starts off by referring to the establishment of the complete system of judicial remedies for the review of the legality of EU acts. This methodological choice reflects the integrationist character of the judgment which is also illustrated by the strengthening of the narrow reading of the CFSP exclusion that the Court put forward. Whilst in $H$ this was based on the exceptional nature of the exclusion, the judgment in Rosneft adds the principle of effective judicial protection, enshrined in Article 47 of the Charter, as yet another argument to that effect. In doing so, not only does the Court develop further the main theme of its approach to its exceptional jurisdiction, but it also introduces a human rights perspective to it: the extension of the procedural mechanisms on the basis of which its jurisdiction could be exercised is presented as essential to ensuring respect for fundamental human rights. The judgment, therefore, provides a richer conception of the Court's role in CFSP matters. It also, suggests a degree of normalization of CFSP in so far as it brings its rules closer to the mainstream legal principles that apply to the other areas of EU law in general, and EU external action in particular.

In essence, the integrationist logic of the judgment in Rosneft is based on the notion that the validity of CFSP decisions over which the Court has jurisdiction

${ }^{88}$ Case C-72/15 Rosneft ECLI:EU:C:2016:381, para, 74.

89 ibid, paras 78 (with reference to Case C-315/85 Foto-Frost ECLI:EU:C:1987:452, para 17 and Case C-362/14 Schrems EU:C:2015:650, para 62) and 80. The Court also stressed that it was 'best placed to give a ruling on the validity of acts of the Union', given the procedural advantages that the preliminary reference procedure affords (it may obtain observations from Member States and the EU institutions and request all Member States and institutions to provide all the information that it considers necessary for the purposes of the case before it) (para 79). 
(that is those which provide restrictive measures for private and legal persons) may only be reviewed by the Court of Justice. This is made clear by the emphasis on Foto-Frost and the main constitutional principle of judicial review that that judgment introduced, according to which national courts are prevented from declaring EU measures invalid. Striving to avoid potential conflicts between national courts and the Court of Justice is a sensible task and a worthwhile and optimal policy objective. The question, however, is whether, attractive though it may be, this outcome in this specific policy context is consistent with primary law.

The answer to this question is negative. The integrationist logic of the judgment in Rosneft is based on a selective reading of the Treaties. The textual argument misconstrues the wording of Article 24(1) TEU and Article 275 TFEU: the former provision qualifies the reference to 'certain decisions' that fall within the Court's jurisdiction 'as provided for by the second paragraph of Article 275 [TFEU]; and the latter refers expressly to 'proceedings, brought in accordance with the conditions laid down in the fourth paragraph of Article 263 [TFEU]'. The wording of Article 24(1) subparagraph $2 \mathrm{TEU}$, therefore, provides no indication that an annulment action would constitute merely an example of the procedure aiming to review the legality of CFSP measures. ${ }^{90}$ The judgment promotes its effet utile interpretation by other similarly questionable arguments. The significance, for instance, of Article 267 TFEU is an observation about the system of judicial review in the EU legal order, but does not amount to an argument in order to read the procedure into the exceptional scheme of review reserved in the Treaties for CFSP measures. If anything, the argument could be the reverse: rather than relying upon the objectives of the preliminary reference procedure in order to extend jurisdiction, the Court could have relied on the objectives of the CFSP exclusion and the two related exceptions in order to determine the applicability of the preliminary reference procedure. The Court refrained from making the latter choice, hence underlining the language of integration into which the judgment was couched.

In this vein, the Court's reference to the Member States in the implementation of CFSP measures was one-dimensional: it ignored their relevance not only to the construction of CFSP as a distinct policy area, albeit within the system of the Union's integrated external action, but also to the very exclusion of that area from the jurisdiction of the Court. It is

90 In his Opinion, AG Wathelet suggested that the reference to art 275 TFEU in art 24(1) TEU was not about the procedure for legality review, but about 'decisions providing for restrictive measures against natural or legal persons adopted by the Council on the basis of Chapter 2 of Title V of the [EU] Treaty': ECLI:EU:C:2016:381, para 61. Also, for the view that the wording of the above provisions could cover preliminary references, see G De Baere, Constitutional Principles of EU External Relations (OUP 2008) 51-4; and T Tridimas, 'The European Court of Justice and the Draft Constitution: A Supreme Court for the Union?' in T Tridimas and P Nebbia (eds), European Union Law for the Twenty-First Century: Rethinking the New Legal Order vol I (Hart Publishing 2004) 113, 128. 
precisely because of the position of the Member States as the main locus of power in the design and implementation of CFSP that the EU's Courts have only been endowed with exceptional and limited powers. To rely on this feature of CFSP in order to extend the scope of the Court's powers was disingenuous.

The broad construction of the Court's jurisdiction may appear uncontroversial in the context of a foreign policy system understood as 'unfinished', 'incomplete', and 'in a process of transition to the finite and attainable ideal of integrating more fully into the mainstream of European Union law'. ${ }^{91}$ After all, the case law examined in this article reflects the logic of the normalization of the policy, and contributes to the deeper integration of CFSP in the mainstream of EU law. The choice, however, of integration should come from the drafters of the Treaties, rather than the Courts.

The judgment in Rosneft is not the only instance where the Court has been keen to extend the scope of the preliminary reference procedure to areas of policymaking that the drafters of the Treaties sought to keep somewhat apart. Under the Nice Treaty, jurisdiction in the Police and Judicial Cooperation in Criminal Matters (the so-called third pillar, PJCCM) was limited: it was subject to certain conditions and, in any case, did not cover common positions (an instrument that the Lisbon Treaty abolished). Given that it had jurisdiction to rule on the legality of any PJCCM measure other than common positions, the Court held in Gestoras Pro Amnistia and Segi that it also had jurisdiction to rule on the validity and interpretation of a common position parts of which ought to have been adopted by another PJCCM measure. ${ }^{92}$ This approach appears similar to that adopted in Rosneft. There is, however, an important distinction: in Gestoras Pro Amnistia and Segi, the application of the preliminary reference procedure was sanctioned in primary law and extended in case law in order to cover a measure which, for all intents and purposes, ought to have been adopted under a different nomenclature and procedure; in Rosneft, the Court introduced the preliminary reference in an area not provided for expressly under primary law. ${ }^{93}$

The above analysis of the judgment in Rosneft suggests that, in interpreting the procedural aspects of its exceptional powers over CFSP decisions targeting individuals, the Court has extended its jurisdiction contrary to the wording of the Treaties and the ratio of Article 24(1) paragraph 2 TEU and Article 275 TFEU. The question that is, then, raised is whether this bold approach to jurisdiction is matched by a similarly bold approach to adjudicating on the substance of the dispute.

91 R Gosalbo Bono, 'Some Reflections on the CFSP Legal Order' (2006) 43 CMLRev 337, 379.

92 Case C-354/04 P Gestoras Pro Amnistía CLI:EU:C:2007:115, paras 54-55; and Case C-355/ 04 P Segi ECLI:EU:C:2007:116, paras 53-55.

${ }_{93}$ See, to that effect, AG Kokott in her View in Opinion 2/13, ECLI:EU:C:2014:2475, para 94. See also De Baere (n 90) 186, referring to the pre-Lisbon arrangements. 
The answer is negative. In fact, the judgment in Rosneft is characterized by a balance between principle and pragmatism. Once it had construed its jurisdiction widely, the Court went on to dismiss all the claims made by the applicant, that is the target of the Union's restrictive measures in question. This was due to the objectives of the latter, namely the promotion of a peaceful settlement of the crisis in Ukraine, which was held to be consistent with the objectives of the Union's external action set out in Article 21 TEU. These objectives rendered the restrictions on the fundamental human rights of Rosneft regarding the conduct of their business and their property both inevitable and legitimate. Furthermore, as the effective achievement of these objectives involved making political, economic and social choices on the basis of complex assessments, the EU's institutions enjoyed broad discretion to that effect. It was for that reason that neither the principle of proportionality nor that of equal treatment had been violated, as no manifest violation was substantiated..$^{94}$

This balance between boldness on the scope of the Court's jurisdiction and caution on its exercise may appear to suggest that the overall approach emerging from the judgment in Rosneft would not pose any threat to the distinct nature of CFSP. In other words, the Union's Judges would respect the leeway that the EU's decision-making institutions enjoy under Title V TEU, and, in principle, would not interfere unduly with their policy choices. Such a suggestion would be far from outlandish. ${ }^{95}$ In the context of trade measures with foreign policy implications, for instance, it was argued early on that, whilst it was keen to construe the scope of EC law, as it then was, broadly, the Court was loath to interfere with the substantive policy choices made by the EU's institutions in the field of foreign and security policy. ${ }^{96}$

94 The Court also dismissed the other claims against the EU measures: the EU-Russia Partnership and Co-operation Agreement had not been violated, as the latter, in art 99(1)(d), enabled a party to take any measure that it considers necessary for the protection of its essential security interests, particularly in time of war or serious international tension constituting a threat of war, terms that the Court construes widely; the duty of the EU's institutions to state reasons had been complied with, as the aims and context of the contested Decision could have left Rosneft with no doubt about the reasons underpinning the adoption of the restrictive measures in question; no relevant, credible and consistent evidence had been adduced to substantiate misuse of powers; despite the different wording between the CFSP Decision and Regulation 833/2014 in certain respects, the latter could be interpreted consistently with the former. As for the rights of Rosneft of access to the file, and the ensuing rights of defence and effective judicial protection, they ought to have been brought up in direct actions for the annulment of the EU's decisions restricting access to the file.

${ }_{95}$ As Craig has put it, '[i]f the ECJ had competence over the CFSP, I think it is a fantasy problem to imagine that it is suddenly going to start substituting judgment on delicate issues of foreign policy for those taken by the European Council or the Council in its decisions on the CFSP. It would exercise very low intensity review over those issues and would review with a very, very light touch': see evidence in the House of Lords European Union Committee, (2003-04), Oral Evidence, para 28.

96 P Koutrakos, Trade, Foreign Policy and Defence in EU Constitutional Law (Hart Publishing 2001). 
The above qualification, however, ought to be assessed against three broader issues raised by the case law examined in this section. The first is about the wording of the Treaties and the logic of the CFSP exclusion from the Court's jurisdiction: the approach adopted by the case law is quite creative with the former and selective with the latter. Whilst it reflects the integration of CFSP in the Union's revamped constitutional order at Lisbon, the case law is less concerned with conveying the distinct position of the policy that Article 24 (1) paragraph 2 TEU and Article 275 TFEU illustrate. This approach sits uncomfortably not only with the wording of these provisions, but also with the choice of the drafters of the Treaties about the role of the EU Courts that they convey.

Secondly, the case law examined so far requires that the Member States show faith, and trust the Court to exercise its broadly construed jurisdiction with appropriate deference to the substantive policy choices that the EU institutions make. This leap of faith could compensate them for the greater involvement in CFSP that the Court has articulated for itself. This leap of faith, however, entails uncertainty, as it would rely upon the EU Judges to take it upon themselves on a case-by-case basis to respect the broad discretion that is inherent in the conduct of the policy.

Thirdly, the case law examined so far equates impliedly judicial review with the exclusive jurisdiction of the CJEU, and is too quick to dismiss a role for national courts in the context of legality review for CFSP measures. This approach is narrow and at odds with the prominent role of national courts in the Union's legal order. This argument will be explored in the following section.

\section{THE ROLE OF DOMESTIC COURTS}

The article so far has analysed the integrationist approach that emerges from the case law on the Court's jurisdiction in CFSP. The role of domestic courts, however, as an alternative locus for judicial review is worth exploring. This is for two main reasons: it highlights a viable alternative that the case law has ignored, and also explores the options open to applicants in cases where the Court has no jurisdiction under Articles 24(1) TEU and 275 TFEU. After all, the broad interpretation of its scope notwithstanding, there are areas in CFSP policy which the Court's jurisdiction may not reach, such as a CFSP decision that does not provide for restrictive measures against natural or legal persons. While the role of domestic courts has not been addressed by the Court of Justice, as the broad approach that it adopted in its case law rendered it redundant, it is, nonetheless, significant for the functioning of the CFSP framework. This is all the more so, given the central role of the Member States in the implementation of CFSP measures.

In addition to questions of validity and interpretation, the role of national courts is also raised in the context of actions for damages. Article 275(1) TFEU does not refer to this remedy. And whilst it read its jurisdiction in 
preliminary references into the provision for annulment proceedings in Articles 24(1) TEU and 275(1) TFEU, the Court's interpretative ingenuity may not be able to stretch so far as to cover damages actions too. The General Court held in $\mathrm{T}-328 / 14$ Jannatian that the above provisions rule out an action for damages from the CJEU's jurisdiction. ${ }^{97}$ This conclusion confirmed the pre-Lisbon case law, according to which both the Court of First Instance, as it then was, and the Court of Justice had held that such an action in the third pillar (Police and Judicial Cooperation in Criminal Law) was manifestly inadmissible. ${ }^{98}$ The argument to the contrary ${ }^{99}$ is not supported by either the wording or the context of Articles 24 TEU and 275 TFEU.

The starting point for our analysis of the role of national courts is the applicability of the rule of law and fundamental human rights to CFSP as a matter of EU law. Article 2 TEU makes it clear that these are included in the values on which the EU legal order is founded. This provision forms part of the General Provisions of TEU and, therefore, applies to all EU policies, including the CFSP. As fundamental human rights are protected in the EU legal order pursuant to the Charter of Fundamental Rights of the European Union (the Charter) which has the status of primary law, ${ }^{100}$ and given that the Charter's provisions 'are addressed to the institutions, bodies, offices and agencies of the Union' (Article 51 Charter), without ruling out specific areas of activities, it follows that the Charter is applicable to CFSP measures. ${ }^{101}$ This has specific implications for the legality of what the EU does in the area. As the Court of Justice put it in Segi, the applicability of the rule of law suggests that 'the institutions are subject to review of the conformity of their acts with the treaties and the general principles of law, just like the Member States when they implement the law of the Union'. ${ }^{102}$ It is noteworthy that, whilst rendered in the pre-Lisbon days, that was a judgment by the Grand Chamber in the context of the second and third pillar where the Court had no and limited jurisdiction respectively. The above conclusion is also supported by other strands of the case law according to which the Charter is addressed to the EU institutions even when they act beyond the EU legal framework. ${ }^{103}$ It would be bizarre in the extreme for the Charter to apply to what the EU institutions do beyond the EU legal framework, but not within the CFSP framework.

97 T-328/14 Jannatian v Council ECLI:EU:T:2016:86, paras 30-33.

98 Case C-354/04 P Gestoras Pro Amnistia and Others v Council ECLI:EU:C:2007:115, paras 46-48; and Case C-355/04 P Segi and Others v Council ECLI:EU:C:2007:116 paras 46-48 (confirming the findings in Case T-333/02 Gestoras Pro Amnistia and Others $v$ Council, not reported, and Case T-338/02 Segi and Others v Council ECLI:EU:T:2004:171, respectively).

99 See M-G Garbagnati Ketvel, 'The Jurisdiction of the European Court of Justice in Respect of the Common Foreign and Security Policy' (2006) 44 ICLQ 77, 116-17. ${ }^{100}$ Art 6(1) TEU.

101 For their application to CFSP international agreements concluded in the context of the EU's anti-piracy operation Atalanta, see Thym (n 28).

102 Case C-355/04 P Segi and Others v Council ECLI:EU:C:2007:116, para 51.

103 See Joined Cases C-8/15 P to C-10/15 P Ledra Advertising Ltd and others ECLI:EU: C:2016:701, para 67. 
Having established that CFSP measures are governed by EU law on judicial protection and fundamental human rights under the current constitutional arrangements, the question of enforcement is raised for the cases where the Court has no jurisdiction under Article 24(1) paragraph 2 TEU and Article 275 TFEU. This is where the role of national courts emerges. In fact, this brings us back to the very principle that underpins the logic of the broad approach adopted by the Court in Rosneft: the EU legal order provides for a complete system of remedies and procedures. Whilst it has been relied upon in order to extend the scope of the Court's jurisdiction, this principle is, in fact, about two judicial actors, namely the CJEU and domestic courts. The role of the latter is stressed in Article 19(1) subparagraph 2 TEU which imposes on Member States a duty to 'provide remedies sufficient to ensure effective legal protection in the fields covered by Union law'. Introduced at Lisbon in order to reflect prior case law, ${ }^{104}$ this provision does not define the term 'in the fields covered by Union law' further. Its scope, therefore, does not rule out CFSP measures, neither is Article 19 TEU itself part of Title V TEU where the CFSP rules are laid down. Actions in relation to CFSP measures, therefore, are not excluded from Article 19 TEU in principle. This conclusion is also supported by Advocate General Kokott in her View in Opinion 2/13 where she argued that, 'in matters relating to the CFSP, effective legal protection for individuals is afforded partly by the Courts of the EU (second paragraph of Article 275 TFEU) and partly by national courts and tribunals (second subparagraph of Article 19(1) TEU and Article 274 TFEU)'. ${ }^{105}$

National courts are, therefore, an intrinsic part of the Union's judicial system and the remedies provided under national law are integrated in the EU's system of remedies. This link has been a long-standing theme in the Court's case law. Not only is it encapsulated by the oft-repeated term 'a complete system of legal remedies and procedures', ${ }^{106}$ but it was also stressed in Opinion 1/09: drawing on Article 19(1) TEU, the Court referred to national courts, along with the CJEU, as 'the guardians' of the EU legal order ${ }^{107}$ and described the tasks attributed to them as 'indispensable to the preservation of the very nature of the law established by the Treaties'. ${ }^{108}$ In fact, rather than exercising the right to grant such remedies, national courts are required to do so on the basis of the duty of cooperation which binds all organs of the Member States pursuant to Article 4(3) TEU. ${ }^{109}$ Linking this role of national courts with the role of the Court of Justice, the latter held in Opinion 1/09 that 'it is for the national

\footnotetext{
104 See, for instance, Case C-50/00 P UPA ECLI:EU:C:2002:462 where the Court held that 'it is for the Member States to establish a system of legal remedies and procedures which ensure respect for the right to effective judicial protection' (para 41).

105 View, Opinion 2/13, ECLI:EU:C:2014:2475, para 103.

106 See, amongst others, Case C-263/02 P Jégo-Quéré ECLI:EU:C:2004:210, para 31, Opinion 1/09 re: European and Community Patents Courts ECLI:EU:C:2011:123 para 70.

107 Opinion 1/09 re: European and Community Patents Courts ECLI:EU:C:2011:123, para 66.

108 ibid, para 85.

109 ibid, para 68. See also Case C-583/11 P Innuit ECLI:EU:C:2013:625, para 91.
} 
courts and tribunals and for the Court of Justice to ensure the full application of European Union law in all Member States and to ensure judicial protection of an individual's rights under that law'. ${ }^{110}$

Whilst Article 24(1) paragraph 2 TEU and Article 275 TFEU restrict the jurisdiction of the Court of Justice in CFSP, such restriction is not introduced, neither does it follow in relation to the jurisdiction of national courts. In fact, in the absence of access to the CJEU in CFSP matters, jurisdiction remains with the national court. This is also the position in relation to competence under Article 4(1) TEU which acknowledges that 'competences not conferred upon the Union in the Treaties remain with the Member States'. There is no reason why a different principle should apply to jurisdiction. ${ }^{111}$ In the pithy words of Lenaerts and his co-authors, "the Union courts do not have inherent jurisdiction just because matters of Union law are involved in a particular case. Instead, there must be a specific legal basis set down in the Treaties which delineates the extent of the Union courts' power to adjudicate a particular case or cause of action. Consequently, everything falling outside of what the Treaties confer upon the Union courts falls within the residual competences of the national courts. ${ }^{112}$

This conclusion is borne out by Article 274 TFEU which refers expressly to actions involving the $\mathrm{EU}$ as a party that are not excluded from the jurisdiction of national courts. ${ }^{13}$ It also follows from the Charter of Fundamental Rights Article 47 of which provides that '[e]veryone whose rights and freedoms guaranteed by the law of the Union are violated has the right to an effective remedy before a tribunal in compliance with the conditions laid down in this Article'. The wording of this provision is broad ('a court') and does not confine its application to the CJEU. It follows from the above that, in the absence of the jurisdiction of the Court of Justice to rule on a dispute pertaining to CFSP pursuant to Article 25(1) paragraph 2 TEU and Article 275 TFEU, jurisdiction stays with domestic courts. ${ }^{114}$

The analysis so far suggests that the broad approach to its jurisdiction that the Court has adopted is by no means essential in order to ensure compliance with the rule of law in CFSP. Put differently, a narrow construction of the Court's jurisdiction, in accordance with the wording of the Treaties and the logic of

110 Opinion 1/09 re: European and Community Patents Courts ECLI:EU:C:2011:123, para 68

111 See AG Kokott in her View in Opinion 2/13, ECLI:EU:C:2014:2475, para 96.

112 K Lenaerts, I Maselis and K Gutman, EU Procedural Law (Oxford University Press 2014) 3.

113 Art 274 TFEU reads as follows: 'Save where jurisdiction is conferred on the Court of Justice of the European Union by the Treaties, disputes to which the Union is a party shall not on that ground be excluded from the jurisdiction of the courts or tribunals of the Member States.'

${ }_{114}$ This position has also been acknowledged by a number of Advocates General: see AG Kokott in her View in Opinion 2/13 ECLI:EU:C:2014:2475, para 99, AG Wahl in Case C-455/14 HP ECLI: EU:C:2016:212, para 99 (where he advised the Court, albeit unsuccessfully, to conclude that it lacked jurisdiction and that the applicant ought to have challenged the contested measure before the Italian courts 'requesting a declaration of inapplicability of the contested decisions and/or reparation of the damages'), and earlier, AG Mengozzi in C-355/04 P Segi in paras 99ff. 
the CFSP exclusion, would not entail the absence of judicial review. National courts act as EU courts and apply EU law in actions against EU measures or national measures adopted within the scope of EU law. Such actions would be raised in different contexts. They may be direct: for instance, a private or legal person may bring an action against an EU institution before domestic courts seeking judicial review (a scenario provided for in Article 274 TFEU). They may also be indirect: for instance, a private or legal person may bring an action against national authorities for their implementation of CFSP measures, in the context of which the legality of the latter may be raised. After all, the provisions of the Charter are also addressed to the Member States 'when they are implementing EU law' pursuant to Article 51(1) Charter, a provision that has been construed broadly by the Court in order to cover any action by a Member State 'within the scope of EU law'. ${ }^{115}$ Finally, actions for damages against the EU or the Member States may be brought before national courts. ${ }^{116}$ In such actions, the EU would not enjoy immunity. ${ }^{117}$

Such actions before national courts raise certain questions. First, how intense is the review of the content of CFSP acts that national courts may exercise? Secondly, what is the effect of a judgment of a national court on the validity of a CFSP measure in the light of the Foto-Frost principle which prevents national courts from declaring EU measures invalid? ${ }^{118}$ Thirdly, what standards are national courts to apply in the context of an action for damages?

In cases where the EU's judges have ruled in favour of the jurisdiction of domestic courts, they have not had to confront the above questions. The General Court, for instance, in Case T-271/10 Hv Council (the judgment which was set aside on appeal by the Court of Justice) had concluded that the domestic judges could rule on the legality of the contested measure and, if loss were established, award damages. ${ }^{119}$ This conclusion, however, did not raise any problems regarding the Foto-Frost principle, as the General Court had already held that the contested measure was attributed not to the EU but the Italian State which had delegated to the Head of Mission powers over its seconded staff.

What if attribution was not an issue? In other words, what could a national court do in the context of an action against a CFSP measure attributed properly to the EU but excluded from the jurisdiction of the Court of Justice? In her View in Opinion 2/13, Advocate General Kokott argued that such courts could disapply a CFSP act in a particular dispute. Such approach would not run

\footnotetext{
115 Case C-617/10 Akerberg Fransson ECLI:EU:C:2013:105 paras 21-22, subsequently endorsed in, amongst others, Case C-206/13 Siragusa ECLI:EU:C:2014:126.

116 See AG Mengozzi in C-355/04 P Segi at paras 133-155.

117 See Protocol No 7, on the privileges and immunities of the European Union, implementing art 343 TFEU. See F Naert, 'European Union Common Security Defence Policy Operations' in A Nollkaemper and I Plakokefalos (eds), The Practice of Shared Responsibility in International Law (Cambridge University Press 2017) 669, 692.

118 Case 314/85 Foto-Frost ECLI:EU:C:1987:452.

119 Case T-271/10 Hv Council ECLI:EU:T:2014:702, para 53.
} 
counter to the Foto-Frost principle, as, in her view, 'in the context of the CFSP, the Court of Justice cannot claim its otherwise recognized monopoly on reviews of the legality of the activities of EU institutions, bodies, offices and agencies. The settled case law of the Court, stemming from the judgment in Foto-Frost, ... cannot, ... in my view, be applied to the CFSP. Unlike in supranational areas of EU law, there is no general principle in the CFSP that only the Courts of the EU may review acts of the EU institutions as to their legality'. ${ }^{120}$ A somewhat more narrow approach is adopted by Advocate General Wahl in his Opinion in Case 455/14 P $H$ where he argued that a national court could suspend the applicability of a CFSP act and award damages. ${ }^{121}$ It is recalled that it is settled case law that a national court has the right to suspend the application of an EU measure provided that certain conditions are met, including a reference to the Court of Justice on the validity of the contested measure. ${ }^{122}$ Advocate General Wahl added that, given that the Court has no jurisdiction to hear a reference, 'it would then be for the EU institution responsible for the act to draw the necessary inferences from the decision of the national court; by repealing or amending the act whose application vis-à-vis the applicant has been suspended. To be clear: the decision of the national court on the lawfulness of an EU act does not, conversely, have effects erga omnes. ${ }^{123}$

The Foto-Frost principle about the Courts' exclusive jurisdiction to declare EU law invalid was articulated in a legal context within which the Court had full jurisdiction. This, however, is clearly not the case in the field of CFSP. No matter how narrowly the CFSP exclusion is construed, there is a core of CFSP measures which are beyond the Court's jurisdiction. This was acknowledged expressly by the Court itself in Opinion 2/13.124 The scope, therefore, of the Foto-Frost principle should be adjusted accordingly in order to reflect the reduced jurisdiction of the Court of Justice. This adjustment would entail the decoupling of the principle from the exercise of review of EU law in this particular area, given the CFSP exclusion and the ensuing non-applicability of the preliminary reference procedure. ${ }^{125}$ In the light of the above, and the analysis of the role of domestic courts set out in this section,

\footnotetext{
120 View in Opinion 2/13 ECLI:EU:C:2014:2475, para 100.

121 Opinion in Case C-455/14 H P ECLI:EU:C:2016:212, para 103.

122 Joined Cases C-143/88 and C-92/89 Zuckerfabrik ECLI:EU:C:1991:65, paras 23-33, and Case C-465/93 Atlanta ECLI:EU:C:1995:369, paras 32-51.

123 Opinion in Case C-455/14 H P ECLI:EU:C:2016:212, para 103. See also AG Mengozzi in C355/04 P Segi at para 120.

124 Opinion 2/13 (Accession to ECHR) EU:C:2014:2454, para 252.

125 See AG Mengozzi in C-355/04 P Segi at paras 121-130 where, in the pre-Lisbon context, he argued that the conditions on which the Foto-Frost judgment is based were not met in the third pillar. The active involvement of national courts as a substitute for the absence of the jurisdiction of the Union's Courts was suggested by the Court of First Instance, as it then was, in another context: having ruled out its jurisdiction to review smart sanctions adopted by the EU pursuant to a United Nations Security Council Resolution, the General Court articulated in Ayadi a clear role for domestic courts: Case T-253/02 Ayadi ECLI:EU:T:2006:200, paras 151-153. This was after
} 
domestic judges have jurisdiction as a matter of EU law over questions of interpretation and validity of CFSP measures.

Whilst the above argument follows from the CFSP exclusion, the central role of domestic courts in the EU legal order, and the overarching scope of the main tenets of EU law, such as the protection of fundamental human rights, its practical implications may appear to be alarming: 'uncontrolled proliferation of conflicting interpretations' 126 and the disapplication of EU measures in different domestic legal contexts may ensue. This risk, however, is as inevitable as it is inherent in the position of CFSP in the Union's constitutional system. First, the possibility of inconsistency in the interpretation and application of CFSP measures is an inherent part of the constitutional settlement reached by the drafters of the Treaties at Lisbon, and follows from the choice that they made about the limited jurisdiction of the Court of Justice in CFSP. After all, even under the existing rules, national courts are prevented from relying upon the preliminary reference procedure for questions about the validity and interpretation of CFSP acts in general (that is except for decisions providing for restrictive measures against natural or legal persons). ${ }^{127}$

Secondly, a degree of uncertainty is not alien to the functioning of the EU legal order. After all, the very foundation of EU law, that is the principle of supremacy, is applied by national constitutional courts somewhat conditionally: on the one hand, there is an overall qualification in Germany about the protection of fundamental human rights, and, on the other hand, it is the ongoing acceptance by the national legislatures, rather than the case law of the Court of Justice on the inherent characteristics of the EU, that is central to the application of supremacy by domestic courts. ${ }^{128}$ Messiness, therefore, and the constant prospect of upsetting the delicate constitutional balance between EU and national law is a challenge with which the EU legal order is familiar as a matter of practice.

Thirdly, the CFSP case is not the first legal context within which the drafters of the Treaties have accepted the possibility of inconsistent interpretations of EU law. The Amsterdam Treaty, for instance, had introduced a variation on the preliminary reference procedure in the area of police and judicial

its much criticized judgment in Case T-315/01 Kadi v Council and Commission ECLI:EU: T:2005:332, subsequently overturned by Case C-402/05 Kadi ECLI:EU:C:2008:461.

126 Editorial, 'The CFSP under the EU Constitutional Treaty: Issues of Depillarization' (2005) 42 CMLRev 325, 327.

127 This possibility had been raised at the preparatory work for the drafting of the Treaty Establishing a Constitution for Europe (CONV 689/1/03 REV 1 Supplementary report on the question of judicial control relating to the common foreign and security policy, 16 April 2003), but the discussion at the relevant Working Group was divided on the issue of the Court's jurisdiction in CFSP: CONV 734/03 Articles on the Court of Justice and the High Court 12 May 2003).

${ }^{128}$ See B De Witte, 'Direct Effect, Primacy, and the Nature of the Legal Order' in P Craig and G De Búrca, The Evolution of EU Law (2nd edn, Oxford University Press 2011) 323. This point is also made in Hinarejos ( $\mathrm{n} 42$ ) 175-6. 
cooperation in criminal matters whereby Member States could choose to confine the right to refer to courts of last resort. ${ }^{129}$

Fourthly, even if the EU was reluctant to acknowledge the role of national courts in CFSP, the latter might well be willing to assume it on their own accord. If anything, the German Solange experience suggests that the idea of an area of EU activity not subject to judicial review would be intolerable to national courts, let alone contrary to the general principles of EU law pursuant to Article 6(3) TEU.

Whilst the risk of inconsistency is the inevitable consequence of the system of judicial supervision in the field of CFSP as set out in the Treaties, the sense of alarm that it appears to generate may be exaggerated. It does not follow, for instance, that domestic courts would be keen to interfere unduly with the conduct of CFSP. A case in point is an action about the capture, detention and transfer of nine suspected Somalian pirates, in the context of the EU's anti-piracy Operation Atalanta, ${ }^{130}$ by German personnel to the Kenyan authorities for criminal proceedings and sentencing in 2009. This action was brought before the Administrative Court of Cologne and, on appeal, the Obervelwaltungsgericht Nordrhein-Westfalen. Whilst the Appeal Court accepted that the EU was responsible for the Operation in principle, it attributed the contested act to the German authorities in the light of the circumstances of the case, and held that the surrender of the suspected pirates to Kenya had been unlawful and in violation of Article 3 ECHR. ${ }^{131}$ In this case, therefore, no EU measure was struck down, as national courts focused on and invalidated a domestic measure, albeit in the context of an EU operation.

It does not follow, of course, that national courts would always confine themselves to reviewing national measures, neither is it suggested that they should. After all, in reviewing CFSP acts, national courts act as EU courts. ${ }^{132}$ This proposition, however, also suggests that national courts are bound by the duty of cooperation under Article 4(3) TEU. ${ }^{133}$ While the latter requires that they carry out judicial review of CFSP measures in order to ensure compliance with fundamental human rights, it also suggests that, in doing so, national courts ought to take into account the effectiveness of EU law. ${ }^{134}$

\footnotetext{
129 This point is emphasized by AG Mengozzi in his Opinion in C-355/04 P Segi at paras 128129.

${ }^{130}$ Council Joint Action 2008/851/CFSP on a European Union military operation to contribute to the deterrence, prevention and repression of acts of piracy and armed robbery off the Somali coast [2008] OJ L 301/33.

131 See the overview in J Heliskoski, 'Responsibility and Liability in CSDP Operations' in S Blockmans and P Koutrakos (eds), Research Handbook on CFSP/CSDP (Elgar Publishing, forthcoming).

${ }^{132}$ See C Hillion, 'Decentralised Integration? Fundamental Rights Protection in the EU Common Foreign and Security Policy' (2016) 1 European Papers 55, 65.

${ }^{133}$ On the duty enshrined in art 4(3) TEU, see M Klamert, The Principle of Loyalty in EU Law (Oxford University Press 2014).

134 For the duty of national courts to take into account the effectiveness of EU law, see Case C212/04 Adelener ECLI:EU:C:2006:443, para 122.
} 
Viewed from this angle, striking down CFSP measures would not become a tool likely to be abused. ${ }^{135}$ In other words, the role of national judges in this field may not be carried out independently of the overall constraints that the EU legal order imposes on them where they act as EU courts.

\section{CONCLUSION}

This article made three main arguments. First, the CFSP exclusion from the Court's jurisdiction should be taken seriously, as it reflects the constitutional ambivalence that characterizes the position of CFSP in the Union's legal order. Secondly, by interpreting the CFSP exclusion narrowly and the exceptions laid down in Article 24(1) TEU and Article 275 TFEU broadly, the case law of the Court of Justice has adopted an integrationist approach that does not reflect accurately either the wording of primary law or the spirit of the system of judicial review that the drafters of the Treaties set out for this policy area. Thirdly, the approach adopted by this case law is not the only way to ensure that the Union's foreign and security policy is carried out in accordance with the rule of law: domestic courts are an essential part of the CFSP system laid down in primary law, and their role has been unduly ignored.

Effective judicial review in the area of CFSP requires a leap of faith. So far, it has been the case law of the Court of Justice that has suggested that the other EU institutions and the Member States show faith: the broad approach to the scope of its jurisdiction in CFSP is accompanied by low intensity of judicial review and deference to the discretion of the Union's decision-makers. It, therefore, appears to reassure the latter that the Union's Judges would be reluctant to unravel the carefully negotiated arrangements reached in areas of considerable political sensitivity. This article proposed a different leap of faith: it is high time that the Court of Justice acknowledged the role of domestic courts and recognized them as a central locus of judicial review in the field. In doing so, the Court would be faithful to the wording of the Treaties and the choices of their drafters about judicial supervision of CFSP measures. It would also grant 'the powerhouse' of EU law ${ }^{136}$ a role commensurate to the central position that Member States have in the conduct of CFSP. Finally, it would show confidence in the maturity of the EU legal order and the effectiveness of its decentralized system of enforcement.

135 See, for instance, the duty imposed on a domestic court that considers suspending the application of an EU measure to take into due account the EU's interests: Joined Cases C-143/88 and C-92/89 Zuckerfabrik, (n 122) above, para 33.

136 D Edward, 'National Courts - The Powerhouse of Community Law' (2002-3) 5 CYELS 1. 